\title{
Ab-initio Calculation Study of Electronic Band Structure of CdTe with Low-index Surface
}

\author{
O.M. Chernikova ${ }^{1}$, Y.V. Ogorodnik², V.V. Prokopiv ${ }^{3}$ \\ ${ }^{1}$ Kryviy Rih National University, 11, Vitaliy Matusevych St., 50027 Kryviy Rih, Ukraine \\ 2 Radiation Monitoring Devices, inc. USA \\ ${ }^{3}$ Vasyl Stefanyk Precarpathian National University, 57, Shevchenko St., 76018 Ivano-Frankivsk, Ukraine
}

(Received 21 March 2021; revised manuscript received 15 June 2021; published online 25 June 2021)

\begin{abstract}
In this paper, the electronic properties of CdTe (100) films without impurities and with the addition of $\mathrm{O}_{2}$ molecules were investigated based on calculations from first principles. It was found that when the oxygen concentration increases from 8 to $14 \%$, the $\mathrm{O}_{2}$ molecule passes the energy barrier more easily, which indicates an increase in the catalytic activity of the CdTe film. Since oxygen affects the catalytic process, we recorded the movement of the band gap depending on the oxygen concentration. According to the calculated results of the study of small diatomic and triatomic clusters (Te, Cd), we found that the inclusion of oxygen atoms or atoms of other kinds in small clusters (Te, $\mathrm{Cd}$ ) affects the catalytic activity of the studied systems as a whole.
\end{abstract}

Keywords: Ab-initio calculation, Catalysis, Surface, Energy, Band gap.

\section{INTRODUCTION}

Today, a lot of attention is paid to alternative and renewable energy. Among the alternative energy sources, the leading place is occupied by solar energy. This is primarily due to the main benefits of this type of energy [1]. Namely, general availability, environmental friendliness, practical inexhaustibility, the possibility of direct conversion of solar energy in the visible and near-infrared spectrum of radiation into thermal or electrical energy. Therefore, in recent years, scientists have made significant efforts to study CdTe as the basis for thin-film solar cells [2-4]. This material has a high absorption coefficient from $1 \times 10^{4}$ to $5 \times 10^{5} / \mathrm{cm}$. The band gap of this semiconductor is $1.5 \mathrm{eV}$, which is very close to the optimal band gap for solar cells with one transition. Therefore, solar cells based on CdTe, are of great interest.

Also, an important step in improving CdTe-based structures is solving the problem of creating a material with predefined physical properties $[5,6]$. To do this, it is important to understand the crystal and energy structure of the studied material. The band-energy spectrum of CdTe compounds is well studied [7, 8]. However, the trends of global electronics development require minimization of material costs for production and miniaturization of the final product. That is why in recent decades, researchers have focused on the creation and study of the properties of nanostructured materials.

\section{METHODS AND THEORY OF CALCULATIONS}

In this paper, we are investigated the electronic properties of CdTe (100) films without impurities and with the addition of $\mathrm{O}_{2}$ oxygen molecules are investigated, based on calculations from the first principles. The results were obtained using the software code $[9,10]$, which implements the quantum-mechanical $E\{\rho(\boldsymbol{r})\}=\sum_{\boldsymbol{k}, \lambda} f_{\boldsymbol{k} \lambda} \varepsilon_{\boldsymbol{k} \lambda}-\int \rho(\boldsymbol{r}) V_{e f f}(\boldsymbol{r}) d \boldsymbol{r}+\int \rho(\boldsymbol{r}) V_{\text {ext }}(\boldsymbol{r}) d \boldsymbol{r}+\int \rho(\boldsymbol{r}) V_{e f f}(\boldsymbol{r}) d \boldsymbol{r}+\int \rho(\boldsymbol{r}) V_{\text {ext }}(\boldsymbol{r}) d \boldsymbol{r}+\frac{e^{2}}{2} \int \frac{\rho(\boldsymbol{r}) \rho\left(\boldsymbol{r}^{\prime}\right)}{\left|\boldsymbol{r}-\boldsymbol{r}^{\prime}\right|} d \boldsymbol{r} d \boldsymbol{r}^{\prime}+$ $+E_{x c}\{\rho(\boldsymbol{r})\}$. of the electron density functional [11] and the normpreserving pseudopotential from the first principles of Bechelet, Hemenn, Schleter [12].

The ground states of electron-nuclear systems were revealed by the algorithm of quantum dynamics, if the variables of the electron and nuclear subsystems were optimized at the same time, or by diagonalization of the Kona-Shem matrix, if only electronic variables were determined at fixed atomic backbones.

Following Kona and Shem, the electron density was recorded in terms of busy orthonormal one-particle wave functions:

$$
\rho(\boldsymbol{r})=\sum_{\boldsymbol{k}, \lambda} f_{\boldsymbol{k} \lambda} \varphi_{\boldsymbol{k} \lambda}^{*}(\boldsymbol{r}) \boldsymbol{\varphi}_{\boldsymbol{k} \lambda}(\boldsymbol{r}),
$$

where $f_{k \lambda}$ are the filling numbers of one-particle states; $k$ is the wave vector lying in the nonconducting Brillouin zone; $\lambda$ is the number of energy zones.

$\left[-\nabla^{2}+V_{e x t}(\boldsymbol{r})+\boldsymbol{e}^{2} \int \frac{\rho\left(\boldsymbol{r}^{\prime}\right)}{\left|\boldsymbol{r}-\boldsymbol{r}^{\prime}\right|} d \boldsymbol{r}^{\prime}+V_{x c}(\boldsymbol{r})-\varepsilon_{\boldsymbol{k} \lambda}\right]|\boldsymbol{k} \lambda\rangle=0$,

where $V_{x \boldsymbol{c}}(\boldsymbol{r})$ is the exchange-correlation potential depending on the total exchange-correlation energy $\operatorname{Exc}\{\rho(r)\}$ :

$$
V_{x c}(\boldsymbol{r})=\frac{\delta E_{x c}\{\rho(\boldsymbol{r})\}}{\delta \rho(\boldsymbol{r})} .
$$

Rewriting equation (2) in the form

$$
\left[-\nabla^{2}+V_{\text {ext }}(\boldsymbol{r})-\varepsilon_{\boldsymbol{k} \lambda}\right]|\boldsymbol{k} \lambda\rangle=0,
$$

you can get a one-particle Schrödinger equation with a self-consistent effective potential:

$$
V_{e f f}(\boldsymbol{r})=V_{e x t}(\boldsymbol{r})+V_{c}(\boldsymbol{r})+V_{x c}(\boldsymbol{r}) .
$$

The total energy of the system of interacting electrons is obtained from the equation: 
In these calculations, the one-particle wave function decomposed into a series of plane waves. In this case, the length of the series was chosen so that one atom of the base had about 20-30 plane waves.

Since cadmium telluride has a face-centered lattice with lattice parameters of $6.48 \AA$ and a symmetry axis $\mathrm{Td} 2(\mathrm{~F} 4 \overline{3} \mathrm{~m})$, we took two basic $\mathrm{Cd}$ atoms with coordinates $(0,0,0)$ and $\mathrm{Te}(0.25,0.25,0.25)$, on the basis of which the CdTe film is constructed. This film consisted of 6 atomic layers containing 12 atoms. There were two atoms in each atomic layer. For further calculations, we used the "plate" model. According to this model, we placed two inverted CdTe films at a distance of $16 \AA$ from each other (Fig. 1). In this case, the parameters of the base of the primitive super-cell of the tetragonal type were such that in the $X$ and $Y$ directions it was possible to model an infinite surface of the film, and in the $Z$ direction - free surfaces (100) with a passive coating [13].

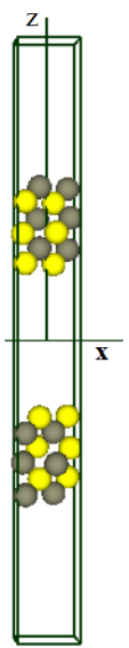

Fig. 1 - Impurity-free CdTe film

Fig. 1 shows an impurity-free CdTe film in which the thickness of the vacuum layer between the "plates" corresponded to $16 \AA$. This distance should be large enough so that two consecutive metal surfaces do not interact with each other. The thickness of the metal plates was about $8 \AA$.

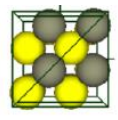

(a)

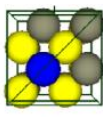

(c)

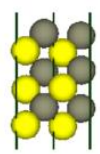

(b)

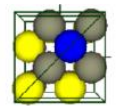

(e)

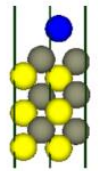

(f)

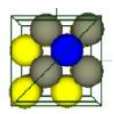

(g)

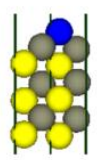

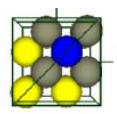

(i)

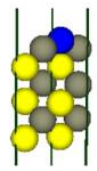

(i)

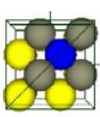

(k)

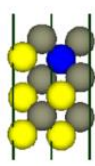

(I)
Fig. 2-Mechanisms of atomic oxygen dissociation on the surface of CdTe (100) and (110), in different positions: over atoms (Fig. 2c, d); over the interatomic void (Fig. 2e, f); at the boundary between atomic emptiness and surface atoms (Fig. 2g, h); in the interatomic cavity (Fig. 2i, j); in the cavity between the surface layers of CdTe (Fig. 2k, l)

To study the mechanisms of dissociation of the $\mathrm{O}_{2}$ molecule on the surface of CdTe (100) and (110), we created the following calculation models:
1) Model of impurity CdTe film (Fig. 2a, b).

2) Model of the CdTe surface with atomic oxygen from the dissociated $\mathrm{O}_{2}$ molecule in different positions (Fig. 2). 3) Model of CdTe surface with adsorbed $\mathrm{O}_{2}$ molecule in different positions in Fig. 3.

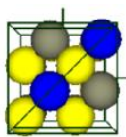

(a)

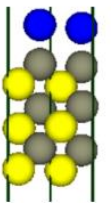

(b)

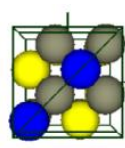

(c)

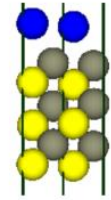

(d)

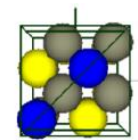

(e)

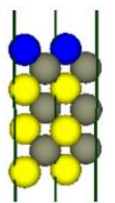

(f)

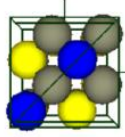

(g)

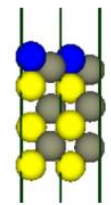

(h)

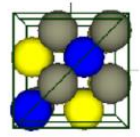

(i)

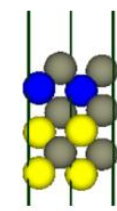

(j)
Fig. 3 - Mechanisms of dissociation of the $\mathrm{O}_{2}$ molecule on the surface of CdTe (100) and (110) in different positions: over atoms (Fig. 3a, b); over the interatomic void (Fig. 3c, d); at the boundary between atomic emptiness and surface atoms (Fig. 3e, f); in the interatomic cavity (Fig. 3g, h); in the cavity between the surface layers of CdTe (Fig. 3i, j)

\section{RESULTS OF THE CALCULATION AND DISCUSSION}

For comparative analysis, we obtained the distributions of valence electrons by energy zones and the intersections of the spatial distributions of valence electron density in the planes (100) and (110) of the sixlayer film CdTe. In the figures below (Fig. 4, Fig. 5), the distribution of electrons in the energy zones for the Gstate is given. Where the horizontal axis stores energy in atomic units, and the vertical number of states per elementary energy interval.

According to Fig. 4, when the location of atomic oxygen from the dissociated $\mathrm{O}_{2}$ molecule on the surface of CdTe in different positions, the highest probability of finding this atom corresponds to the position above the Te atom. This result is obtained from the comparative characteristics of the total energy for the abovedescribed film systems. From Fig. $4 \mathrm{~b}$ it is seen that the minimum range corresponds to a value from $E=-249.79$ a.u.e. (atomic units of energy) to $E=-41.47$ a.u.e. with the maximum population of the states of the valence band 7 . The number of allowed states was determined by half the number of electrons (due to disregard for the electron spin). When the $\mathrm{O}_{2}$ molecule is located on the surface of CdTe (100) (Fig. 5), the minimum energy range corresponds to the location of the oxygen molecule in the cavity between the surface layers of CdTe. This value is from $E=-237.24$ a.u.e. to $E=-45.6$ a.u.e. (Fig. 5 e). The maximum population of the valence band states in this case is 6 . That is, when an oxygen molecule is added, the energy of the CdTe film gradually decreases, which indicates an increase in its catalytic activity. Also, when the oxygen concentration changes from $8 \%$ to $14 \%$, it is possible to predict an improvement in the deposition quality of the CdTe film. That is, to achieve the growth of films with predetermined electrical and structural parameters [14-16]. We recorded the movement of the band gap depending 
on the oxygen concentration. Comparing the CdTe film with adsorbed oxygen at the boundary between the atomic void and surface Te atoms (Fig. 6a) and the CdTe film with the adsorbed $\mathrm{O}_{2}$ molecule in the cavity between the surface layers of CdTe (Fig. 6b), it is seen that with increasing oxygen concentration, the width of the band gap decreases.
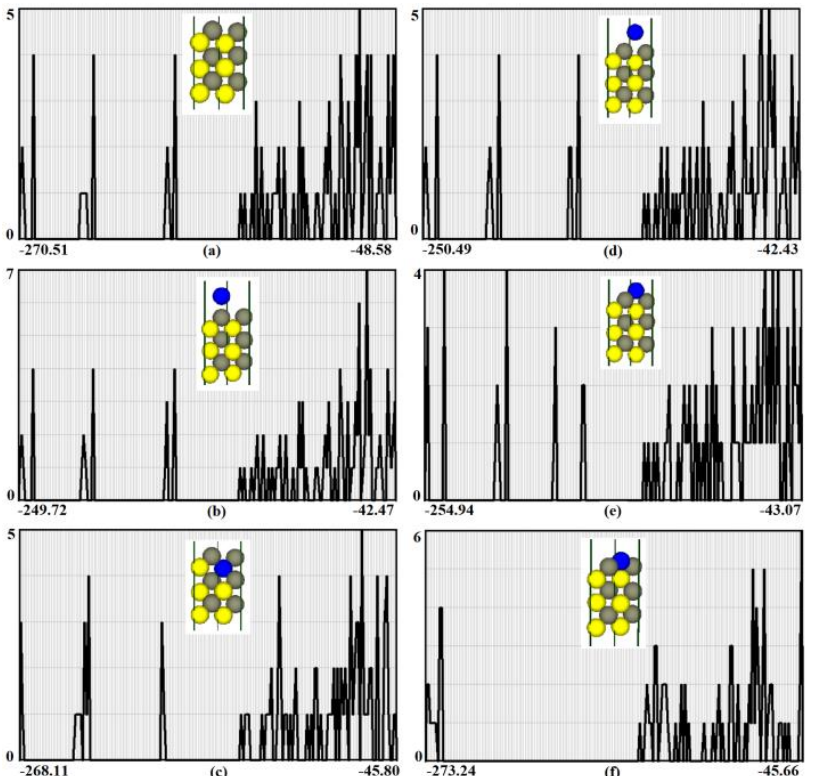

Fig. 4 - Distribution of valence electrons by energy zones for atomic oxygen on the surface of CdTe (100): (a) impurity-free CdTe film; (b) over Te atoms; (c) in the cavity between the surface layers of CdTe; (d) over the interatomic void of surface Te atoms; (e) at the boundary between the atomic void and the surface atoms of Te; (e) in the interatomic void of Te atoms
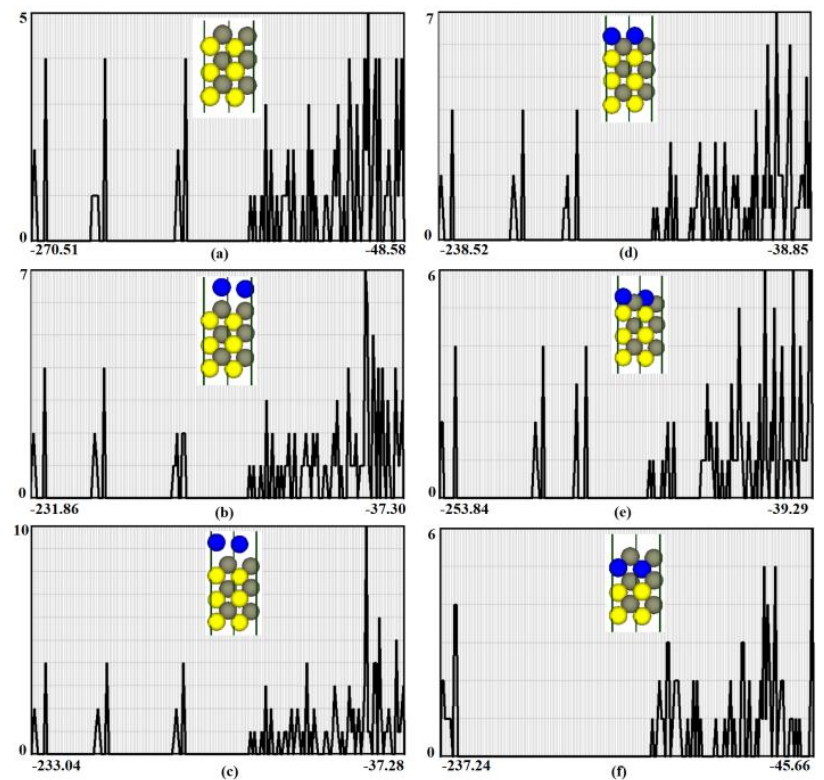

Fig. 5-Distribution of valence electrons by energy zones for the surface of CdTe (100) with adsorbed $\mathrm{O}_{2}$ molecule: (a) impurity CdTe film; (b) over Te atoms; (c) over the interatomic void of surface Te atoms; (d) at the boundary between the atomic void and the surface atoms of Te; (e) in the interatomic void of Te atoms; (e) in the cavity between the surface layers of CdTe

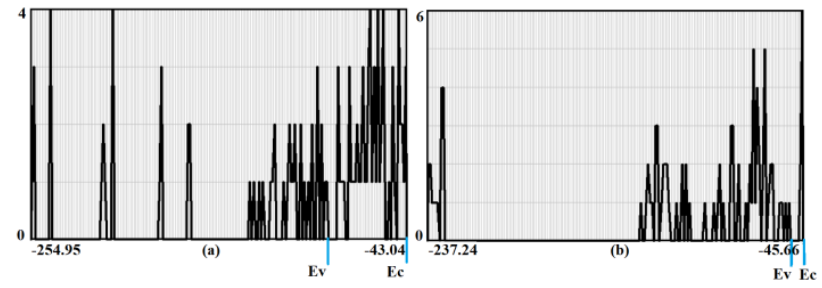

Fig. 6 - Distribution of valence electrons by energy zones for the surface CdTe (100), where $E v$ is the boundary of the valence band, $E c$ is the boundary of the conduction band: (a) with adsorbed oxygen at the boundary between the atomic void and surface atoms Te; (b) with an $\mathrm{O}_{2}$ molecule in the cavity between the surface layers of CdTe

(110)

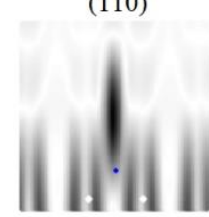

(a)

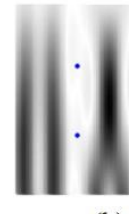

(b)
$(100)$

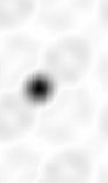

(c)

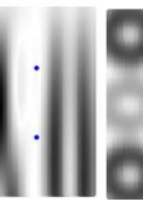

Fig. 7 - Intersections of spatial distributions of valence electron density in mutually perpendicular planes (110) and (100) for the CdTe film in the vicinity of atomic oxygen (a), (b), (c), (d) and $\mathrm{O}_{2}$ molecule (d), with a viewing radius from $3.8 \AA$ to $4.2 \AA$

Fig. 7 shows the cross sections of the spatial distributions of the valence electron density in mutually perpendicular planes (110) and (100) for the CdTe film in the vicinity of atomic oxygen and the $\mathrm{O}_{2}$ molecule with a viewing radius from $3.8 \AA$ to $4.2 \AA$. These calculations are given for comparative analysis with the data of Fig. 4 and Fig. 5. Therefore, the minimum energy range for atomic oxygen corresponds to Fig. $6 \mathrm{a}$, c, and for the $\mathrm{O}_{2}$ molecule - Fig. 7d, e. According to the maximum energy range for atomic oxygen correspond to Fig. 7b, $d$, and for the $\mathrm{O}_{2}$ molecule - Fig. $7 \mathrm{~d}$, i. If we compare the values of the spatial distributions of the valence electron density for the CdTe film with the addition of oxygen (Fig. 7a) and the impure CdTe film (Fig. 7e), we can conclude that the oxygen atom absorbs part of the electron density, reducing the energy of the film.

As can be seen from our calculations, the addition of oxygen to CdTe, contributes to certain changes in the band gap and energy range of the studied system. To understand in detail the local mechanisms that occur on the surface of the CdTe (100) film without impurities and with the addition of $\mathrm{O}_{2}$ oxygen molecules during catalytic reactions, we calculated the distributions of valence electron densities and electronic energy spectra for two and three atomic linear clusters $(\mathrm{Cd}, \mathrm{Te})$. The above-mentioned systems with the addition of atomic oxygen are also calculated. The distance between the atoms in the calculations is given as the sum of the radii of the atoms. No further optimization was performed. 
In Fig. 8 and Fig. 9, the distribution of valence electrons by energy zones for two and three atomic linear clusters (Te, $\mathrm{Cd}$ ) without the addition of atomic oxygen (Fig. 8) and with the addition of atomic oxygen (Fig. 9) is shown.
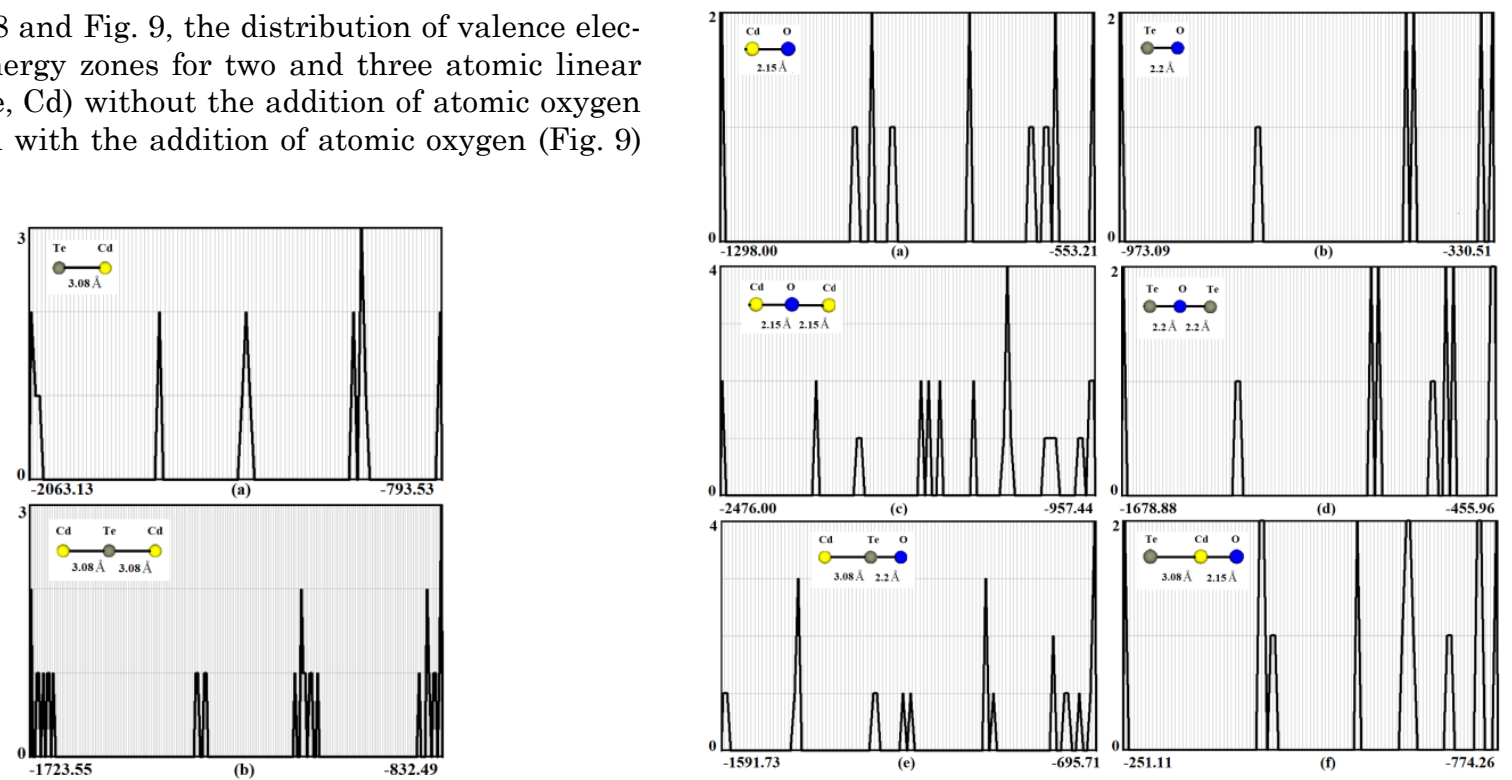

Fig. 9 - Distribution of valence electrons by energy zones of two and three atomic linear clusters $(\mathrm{Cd}, \mathrm{Te})$ with the addition of atomic oxygen: (a) diatomic linear cluster Te-Cd; (b) a triatomic linear cluster Cd-Te-CD; (c) a triatomic linear cluster Te-CD-Te

\section{CONCLUSIONS}

The valence electron densities and electronic energy

Fig. 8 - Distribution of valence electrons by energy zones of two and three atomic linear clusters $(\mathrm{Cd}, \mathrm{Te})$ without addition of atomic oxygen: (a) diatomic linear cluster Te-Cd; (b) a triatomic linear cluster $\mathrm{Cd}-\mathrm{Te}-\mathrm{CD}$; (c) a triatomic linear cluster Te-CD-Te

We found that for diatomic clusters, the reduction of the energy range occurs with the addition of atomic oxygen. Thus, for a diatomic linear cluster Te-Cd (Fig. 8a), the minimum range corresponds to a value from $E=-2063.13$ a.u.e. to $E=-793.53$ a.u.e., and for Te-O (Fig. 9b) this value is from $E=-973.09$ a.u.e. to $E=-330.51$ a.u.e. In this case, for Cd-O (Fig. 9a), this value is from $E=-1298.04$ a.u.e. to $E=-553.21$ a.u.e. We also recorded a decrease in the band gap for the Te$\mathrm{O}$ linear cluster compared to $\mathrm{Cd}-\mathrm{O}$. When an additional $\mathrm{Te}$ (Te-O-Te) or $\mathrm{Cd}$ (Cd-O-Cd) atom is added to a diatomic system, the band gap decreases. Another situation is for Te-Cd systems that do not contain atomic oxygen. When an additional $\mathrm{Cd}$ or Te atom is added to this diatomic cluster, the band gap increases. It can be assumed that the addition of another metal to diatomic clusters $\mathrm{Te}-\mathrm{O}$ and $\mathrm{Cd}-\mathrm{O}$ increases the catalytic activity, which compared to diatomic (Te-Cd) and triatomic (Te$\mathrm{Cd}-\mathrm{Te})$ and $(\mathrm{Cd}-\mathrm{Te}-\mathrm{Cd})$ linear clusters without the addition of atomic oxygen.

\section{REFERENCES}

1. M.A. Green, K. Emery, Y. Hisikawa, W. Warta, E.D. Dunlop, J. Sci.: Prog. Photovoltaics 23, 19 (2015).

2. E. Colegrove, J.H. Yang, S.P. Harvey, M.R. Young, J.M. Burst, J.N. Duenow, D.S. Albin, S.H. Wei, W.K., J. Phys. D: Appl. Phys. 51, 075102 (2018).

3. J.M. Burst, S.B. Farrell, D.S. Albin, E. Colegrove, M.O. Reese, J.N. Duenow, D. Kuciauskas, W.K. Metzger, J. APL Materials spectra for the CdTe (100) and (110) films without impurities and with the addition of oxygen molecules were obtained from the first principles by the methods of the theory of the electron density functional and the pseudopotential.

Our calculations show that the $\mathrm{O}$ atom and the $\mathrm{O}_{2}$ molecule can be on the surface of CdTe (100) at four different initial adsorption positions (above the atom, above the interatomic void, at the boundary between the atomic void and the surface atoms, and in the cavity between the surface layers). Moreover, the most probable location of atomic oxygen is over the Te atom and $\mathrm{O}_{2}$ molecules in the cavity between the surface layers of CdTe. It was also found that when the oxygen concentration increases from $8 \%$ to $14 \%$, the $\mathrm{O}_{2}$ molecule passes the energy barrier more easily, which indicates an increase in the catalytic activity of the CdTe film. Namely, it allows you to control the electrical and structural parameters of the films. We recorded the movement of the band gap depending on the oxygen concentration. According to the calculated results of the study of small diatomic and triatomic clusters (Te, Cd), we found that the inclusion in small clusters (Te, Cd) of oxygen atoms or atoms of other kinds affects the catalytic activity of research systems as a whole.

4, $116102(2016)$.

4. A.H. Munshi, N. Sasidharan, S. Pinkayan, K.L. Barth, W. Sampath, W. Ongsakul, J. Sol. Energy 173, 511 (2018).

5. F. Feng, L.T. NGuyen, M. Nasilowski, B. Nadal, B. Dubertret, A. Maître, L. Coolen, J. ACS Photonics 5, 1994 (2018).

6. V. Dzhagan, A.G. Milekhin, M.Y. Valakh, S. Pedetti, M. Tessier, B. Dubertret, D.R.T. Zahn, J. Nanoscale 8, 17204 (2016). 
7. F. Mezraga, N. Bouarissaa, J. Mater. Res. 22 No 3, e20171146 (2019).

8. G. Fonthal, L. Tirado-Mejía, J.I. Marin-Hurtado, H. ArizaCalderón, J.G. Mendoza-Alvarez, J. Phys. Chem. Solids 61 No 4, 579 (2000).

9. R.M. Balabay, Computational Methods from the First Principles in Solid State Physics: Quantum-Mechanical Molecular Dynamics (Kryviy Rih: Publishing House: 2009).

10. Ab initio calculation, http://sites.google.com/a/kdpu.edu.ua /calculationphysics/.

11. W. Kohn, L.J. Sham, J. Phys. Rev. B 140, 1133 (1965).
12. G.B. Bachelet, D.R. Hamann, M. Schluter, J. Phys. Rev. B 26, 4199 (1982)

13. O.M. Chernikova, Y.V. Ogorodnik, J. Mater. Today: Proc. $\mathbf{3 5}$ No 4, 599 (2021).

14. A. Hu, J. Zhou, P. Zhou, X. Wu, D. Yang, J. Sol. Energy Mater. Sol. Cel. 214, 110595 (2020).

15. B.A. Korevaar, J.R. Cournoyer, O. Sulima, O. Yakimov, J.N. Johnson, J. Prog. Photovolt.: Res. Appl. 22, 1040 (2014).

16. D.S. Albin, Y. Yan, M.M. Al-Jassim, J. Progr. Photovolt.: Res. Appl. 10, 309 (2002).

\section{Дослідження розрахунку ab-initio електронної структури CdTe з низькою індексною поверхнею}

\section{О.М. Чернікова ${ }^{1}$, Я.В. Огородник² ${ }^{2}$ В.В. Прокопів ${ }^{3}$}

${ }^{1}$ Криворізький національний університет, вул. Віталія Матусевича, 11, 50027 Кривий Ріг, Украӥна ${ }^{2}$ Radiation Monitoring Devices, inc. USA

${ }^{3}$ Прикарпатський національний університет Василя Стефбаника, вул. Шевченка, 57, 76018 Івано-Франківськ, Україна

В даній роботі досліджено електронні властивості плівок CdTe (100) без домішок та з додаванням молекул кисню $\mathrm{O}_{2}$ на основі розрахунків із перших принципів. Встановлено, що при збільшенні кон центрації кисню від $8 \%$ до 14 \% молекула $\mathrm{O}_{2}$ легше проходить енергетичний бар'ер, що свідчить про підвищення каталітичної активності плівки CdTe. Так як кисень впливае на каталітичний процес, нами зафіксовано переміщення ширини забороненої зони в залежності від концентрації кисню. Згідно розрахункових результатів щодо дослідження малих двохатомних та трьохатомних кластерів (Те, $\mathrm{Cd})$ нами встановлено, що включення в малі кластери (Te, $\mathrm{Cd}$ ) атомів кисню або атомів іншого роду впливають на каталітичну активність досліджуваних систем в цілому.

Ключові слова: Ab-initio розрахунки, Каталіз, Поверхня, Енергія, Ширина забороненої зони. 